\title{
Berättelser från 1900-talets Eskilstuna
}

\section{Eva Sundgren}

Vardagliga berättelser ger information både om den som berättar och det samhälle som berättelserna utspelar sig i. Jag har fascinerats av många intressanta berättelser i de inspelningar jag gjort i Eskilstuna och vill i den här artikeln dela med mig av några av dem.

Inspelningarna gjordes för projektet Kontinuitet och förändring $i$ nutida talspråk. Aterbesök $i$ Eskilstuna, då jag upprepade Bengt Nordbergs undersökning av den språksociala variationen i Eskilstuna och därigenom kunde se pågående språkförändringar i verklig tid (Sundgren 2002). Jag spelade 1996 in dels de 13 talare som jag lyckades spåra av de 83 som Nordberg spelade in 1967, dels 72 nya informanter. Informanterna i båda inspelningsserierna är infödda Eskilstunabor. I panelstudien jämförs de 13 informanternas tal med hur de talade 29 år tidigare, och $\mathrm{i}$ trendsamplet jämförs de 72 nya talarna med hela 60-talssamplet. Under 2018 har jag spelat in sex av de 13 så kallade paneltalarna en tredje gång.

I den här artikeln fokuserar jag mest på innehållet i berättelserna och ger glimtar från livet i 1900-talets Eskilstuna. Tidigare har jag analyserat hur de 13 paneltalarna berättar om samma händelser i livet med 30 års mellanrum (Sundgren 2003) och äldre personers samtalsstil med exempel på hur min äldsta informant 1996 berättar med inlevelse (Sundgren 2012), och i den här artikeln ges också en sammanfattning av de två tidigare artiklarna med exempel från hur två paneltalare berättar om samma händelser i livet och transkriptionen av en berättelse framförd av den äldsta informanten.

\section{Inspelningarna - situation och stil}

Som betonas i $\mathrm{CA}^{1}$ är enskilda samtalsbidrag kollektiva produkter som gemensamt konstrueras av talare och lyssnare. Det gäller också, anser jag, berättelser i en sociolingvistisk intervju. Bland andra Natalie Schilling-Estes (2002, 2008) har diskuterat stil och William Labovs vernacular ${ }^{2}$ som "bästa" typen av data, och som hon påpekar innehåller alla stilar någon slags performativitet. Det måste också framhållas att Eskilstunainspelningarna är mer informella jämfört med hur den sociolingvistiska intervjun brukar

$1 \mathrm{CA}=$ Conversation Analysis: forskning som fokuserar hur interaktion går till och hur människor organiserar samtal i samspel med varandra. Man studerar naturligt förekommande samtal, och man har ett deltagarperspektiv, d.v.s. sätter sig in i de samtalandes situation för att förstå och förklara vad som sker i samtalet. Man går in i analysarbetet så förutsättningslöst som möjligt och tar bara hänsyn till det som faktiskt avspeglas i själva samtalet (Sundgren 2013: 354).

2 Ung. 'vardagsspråk', det informella språk man talar spontant i vardagliga situationer som i samtal med familjemedlemmar och nära vänner (Sundgren 2013: 368). 
beskrivas. Wolfson (1976) hävdar exempelvis att berättelser som framkallats i en intervjusituation saknar belägg på historiskt presens, och Mats Eriksson (1997) att de spelas in på plats vald av undersökaren. Ingen av dessa beskrivningar stämmer på våra inspelningar. Målsättningen var att spela in ett så naturligt vardagsspråk som möjligt. Stilen är informellt, vardagligt talspråk och vi har kallat dem "samtalsliknande intervjuer", men de flesta inspelningarna har mer prägel av samtal än intervju. Samma typ av ämnen återkommer i flertalet intervjuer: skolgång, arbete, bostad, familj, intressen och staden Eskilstuna. För de yngre informanterna tillkommer framtidsplaner. För de äldre informanterna tillkommer i regel hur staden och samhället har förändrat sig sedan de växte upp. Det är allmänna ämnen med klar personlig anknytning.

När man utgår från ett interaktionellt perspektiv och inte ser berättelser i samtal som färdiga produkter som levereras oberoende av samtalskontexten och den som lyssnar blir det viktigt att diskutera vilket inflytande intervjuaren har på både vad som berättas och hur det berättas. Samtalet konstrueras gemensamt av alla involverade parter. I en sociolingvistisk intervju blir det emellertid knappast fråga om att det är svårt för den som berättar att behålla ordet. Däremot spelar t.ex. mina värderande omdömen roll för hur berättelserna konstrueras.

Jag ville få samtalen att bli spontana och övervinna svårigheterna som ligger i "the observer's paradox", nämligen att talspråksforskarens mål är att "observe the way people use language when they are not being observed" (Labov 1972a: 61). Jag uppmuntrade informanterna att inte dölja personliga känslor och visade stort intresse för vad de berättade för mig och bidrog själv med personliga erfarenheter och upplevelser och visade på det sättet att det var tillåtet att prata om personliga saker. Jag tog fasta på Nordbergs råd (1982: 108) att man bör se samtalet som en byteshandel och att man som bytesvara mot talarens prestation kan ge "visat intresse, sympati, beröm, smicker, skämt, artighet, skvaller”. Mitt intryck är att jag, för det mesta i alla fall, lyckades vinna informanternas förtroende och att de glömde inspelningssituationen när de blev engagerade i ett samtal.

Alla inspelningar 1996 gjordes med hjälp av en bandspelare och två mikrofoner, så kallade "myggor", den ena för informanten och den andra för mig. Jag spelade in minst 45 minuter med varje informant. När samtalet flöt bra och informanten gärna pratade mer satte jag i ett nytt band och som mest spelade jag in 90 minuter. Den genomsnittliga inspelningstiden per informant blev 55 minuter. För de sex paneltalare som spelades in en tredje gång 2018 lade jag min mobiltelefon på bordet och spelade in på röstmemon, också denna gång minst 45 minuter; inspelningstiden 2018 blev i genomsnitt 50 minuter per informant. 


\section{Vad är en berättelse?}

Vad som ska räknas som en berättelse är inte självklart. Det finns olika definitioner också inom sociolingvistisk forskning. Många har använt sig av eller utgått från den modell över den muntliga berättelsens struktur som William Labov konstruerade på 1960-talet (Labov \& Waletsky 1967; Labov 1972b). De två primära funktionerna är enligt Labov den referentiella och den evaluerande. En berättelse återger händelser och samtidigt använder man olika evaluerande medel för att visa att händelsen är intressant och värd att framföras. Enligt Labovs modell innehåller en berättelse fyra obligatoriska element, nämligen orienteringen som placerar händelsen i tid och rum och talar om vilka personer som var inblandade och typen av situation eller aktivitet, handlingen, evalueringen och upplösningen eller resultatet. En berättelse kan också innehålla ett abstrakt, en slags introduktion till berättelsen, och en koda som signalerar att berättelsen är över. Bland andra Schegloff (1997) har emellertid kritiserat att Labovs modell beskriver berättelsen bara som en produkt, inte själv processen $\mathrm{i}$ interaktion med lyssnaren (i omtryck 2003: 107):

In short, there is nothing interactional in the data at all other than the eliciting question, which takes on a role much like that of an experimental stimulus to occasion the production of the already formed story to be told.

Labovs modell fokuserar de strukturella elementen i berättelsen, medan Livia Polanyi (1989) sätter in samtalet och berättandet $i$ ett sociokulturellt sammanhang och fokuserar det semantiska.

Erikssons villkor (1997) för att excerpera berättelser är innehållsliga, nämligen att en berättelse måste skildra en specifik händelse som har inträffat $i$ verkligheten vid en tidpunkt som ligger $i$ det förflutna $i$ förhållande till det tillfälle då berättelsen framförs, funktionellt, nämligen att berättelsen ska ha en poäng, och interaktionellt, nämligen att berättandet ska vara etablerat i samtalet. Catrin Norrby (1998) excerperar "berättelsekandidater" i vardagliga och informella samtal mellan vänner, och hon ger en semantiskt formulerad definition på berättelsekandidat (sid. 58):

En berättelsekandidat återskapar ett från talögonblicket skilt och i tid och rum avgränsat händelseförlopp. *

Händelseförloppet ges antingen explicit uttryck i ytstrukturen eller tolkas genom inferens.

('Med händelseförlopp förstås minst två händelser som har inbördes samband och alltså kan tolkas som att de hör ihop, men där ingen är underordnad den andra.)

I den här artikeln ger jag ingen egen definition av berättelse. Mitt huvudfokus är att ge glimtar från hur det var att leva i Eskilstuna under förra seklet, men jag återger inte bara vad informanterna berättar om olika 
händelser i livet, utan jag ger också några exempel på positiva attityder till staden Eskilstuna.

Genom att konstruera berättelser formar man sin identitet och presenterar sig själv. Erving Goffman (1959) är intresserad av den självbild vi ger genom vår vardagliga kommunikation, och Deborah Schiffrin (1996) beskriver berättelsen som ett självporträtt. Jerome Bruner (1987: 15) hävdar till och med att vi till slut "become the autobiographical narratives by which we 'tell about' our lives". Charlotte Linde (1993) demonstrerar - med berättelser om yrkesval som exempel - hur människor i sina levnadsberättelser (life stories) skapar sammanhang (coherence) i sina liv. Berättaren kan se sig själv på distans, reflektera över sina val och handlingar i efterskott, ge en evaluering (evaluation) och därigenom presentera sig själv som en moraliskt handlande person. Linde (1993: 31) framhåller också att vi ändrar berättelsen om vårt liv efter mottagare, situation och hur vi själva förändras.

Peter Öberg (1997) beskriver hur det levda livet återspeglas i ålderdomen. Verkligheten inte bara återspeglas i berättelser om livet, utan den skapas också. Människor skapar en berättelse av sina liv, och i gerontologisk forskning har man urskilt två huvudperspektiv, nämligen det "framgångsrika" och det "problemfyllda" åldrandet. Livshistorien rekonstruerar mening åt det förflutna utifrån nuets perspektiv (Öberg 1997: 48).

\section{Transkriptionsnyckel}

Transkriptionerna är gjorda med delvis talspråksanpassad ortografi. Det är svårt att återge i tal i skrift och jag har valt en nivå med flera tecken som ska återge det man hör, men samtidigt inte en sådan detaljnivå att det blir svårläst. Till exempel återger jag inte $\mathrm{i}$ denna artikel var samtidigt tal förekommer, dvs. när informanten och jag säger något samtidigt, eller hur långa pauserna är. Den som inte är van att läsa transkriberat tal kan ändå uppleva texten som konstig. De tecken som används i den här artikeln är:

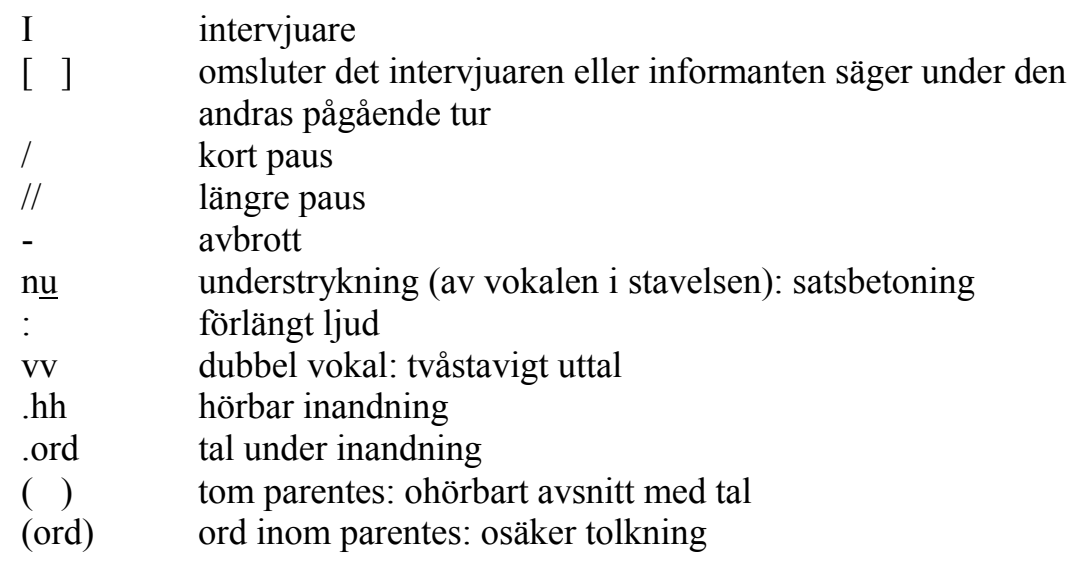




\begin{abstract}
(( )) kommentar eller tolkning av ljud
$\wedge^{\wedge}$ ord $^{\wedge} \quad$ ord mellan cirkumflex: tal under skratt/fniss

*ord* ord mellan asterisker: framställs med förställd röst

Alla personnamn är fingerade.
\end{abstract}

\title{
Hur samma händelser skildras med 30 års mellanrum
}

Det finns händelser i livet som man upplever som så viktiga eller centrala att man berättar dem gång på gång, och jag tror att man har en tendens att forma "stående berättelser" som man till slut minns bättre än själva händelsen. I Mats Erikssons minnesskrift (2003) beskrev jag hur två paneltalare berättar om samma händelser i livet med 30 års mellanrum. Båda kan ses som exempel på det framgångsrika åldrandet (jfr Öberg 1997). Trots att så lång tid hade gått mellan de två inspelningarna kan man se många likheter mellan de två versionerna. Det finns en tendens att ha med olika detaljer i orienteringen. Man fäster en berättelse i tid och rum, och det spelar ibland inte så stor roll till exempel vilken tidpunkt man uppger. Sådana upplysningar ger färg åt berättelsen och kan också skapa en känsla av närvaro (jfr Norrick 2000: 202). Betydelsefulla strategier för berättandet är att använda dialog, evaluering och repetition, och en del fraser i dialogen är nästan ordagrant desamma vid båda tillfällena. Evalueringen ger 1996 i ännu högre grad än 30 år tidigare en positiv bild av informanternas liv. Mitt huvudintryck av de äldre informanternas berättelser 1996, både de i trendundersökningen och de i panelen, är att de ger en positiv bild av sina liv och verkar nöjda, trots att det finns många exempel på berättelser om stora svårigheter. Flera av paneltalarna ger till och med en mer positiv bild av sina liv än de gjorde 30 år tidigare.

I det följande ger jag exempel på hur E73 och E62 berättar om samma händelser. ${ }^{3}$ E73 (född 1919) hade varit lantbrukare på en gård som ligger i utkanten av Eskilstuna och var hela tiden mycket engagerad i stadens idrottsliv. E62 (född 1927) arbetade sig upp inom banken, hade många förtroendeuppdrag och var fackligt aktiv. Han visade mycket stolthet över att han, "en vanlig arbetargrabb från Norr", hade lyckats så bra.

I det första exemplet skildrar E73 de omständigheter som fick honom att sluta ha djur på gården. Först återges hur han berättade för Nordberg och sedan hur han berättade för mig. Jag började min inspelningsserie med att spela in paneltalarna, och den allra första inspelning jag gjorde var med E73.

3 Paneltalarna, dvs. de 13 informanter som spelades in en andra gång 1996, varav sex spelades in en tredje gång 2018, fick samma kod som vid första undersökningen 1967. E1-50 tillhörde socialgrupp 1, enligt den tidens kategorisering i tre socialgrupper, E51-100 socialgrupp 2 och E101-E150 socialgrupp 3. 


\section{E73, inspelad 1967-04-01}

I jaa / hur mycke eh du har djur också

E73 ja har inga djûr seru / för dä där går inte /

för eh förr i tidn då gick dä ju bra här men nu

fick man ju sitta hemma varenda sönda å titta om folk stängde grin̄iar / [jaa] dä har ju bivi den / den orningen på folk å särskilt nu / dom här mopedernas intåg vet du då har dom ju hoftång i fíckan å klipper av trådarna / [hmhm / mm ] så fïck man gå eh varje kväll å laga / all trå [mm] / för annars rink- ringde dom här om nätterna å sa nu ä konna i Nyfōrs / nu ä lom i Grāngärde [((skratt)) / mm] så dä va ente så rolit / [mm] man fick inte hat i fre nånting hellt

I näe nä de måste ju va problem när de ligger så nära

E73 jaa / förr då va ju folk eh / fostrade te dä att eh $\bar{s}^{-}$/ $\ddot{a}$ lä en grinn så ska len stängas / [mm] men du vet dä ä sjlut på dä /

\section{E73, inspelad 1995-12-14}

I va hade ni för jordbruk här / hade ni nå djụr nån gång eller

E73 ㅇj ja / här ja / [ja] / här (ha vi) hästar å grisar å kor å / allting men sen sjluta vi mä kor / nittonhundrasexti / för då kan man gott säja så här att / mopedens / infarande här i samhälle då gíck dä inte / för då stängde inte människer grindar / å då / dom klippte av taggtrådar å / då gick dä inte å hålla på längre / [nää] för dä fanns ett tillstånd här när polisen stog här å lysste (dom) sa så här nu får ni gå efter konna för dom är vi Tunavallen / (på en nå mornar) / för då stängde int- då var dä sjlut mä dä där m- när mopederna kom / dom stängdé ju aldri nåra grindar / ungdomar

I orka inte gå av å s-

E73 ja å sen klippte dom av trådar å dom / vet / [jahá] så då gíick dä inte längre

När jag hör de två versionerna av berättelsen tycker jag det är fascinerande att de låter så lika. Tonfall och uttal bidrar till att det är svårt att tänka sig att det har gått så lång tid mellan inspelningarna. E73 använder liknande ord 
och uttryck vid båda tillfällena, t. ex. mopedernas intåg/mopedernas infarande, och det förekommer repetition av viktig information.

Det är samma huvudsakliga orsaker som anges till att det inte gick att ha kor längre, nämligen att när mopederna kom slutade folk att stänga grindar och klippte av taggtrådar och då försvann korna ut. Vid den första inspelningen berättar E73 att konna hittades i Nyfors och i Grangärdet, men vid den andra inspelningen säger han Tunavallen, som ligger mellan Grangärdet och Nyfors. Som nämnts anges i en berättelse ofta namn och tidpunkter som en orientering till var och när något händer, och det spelar inte någon större roll för själva händelseförloppet vilka namn och klockslag som uppges.

I det andra exemplet berättar E62 hur det gick till när han som 16-åring fick jobb i banken. Utmärkande för hans sätt att berätta är att han ger många detaljer i orienteringen som bakgrundsinformation och att det förekommer mycket dialog.

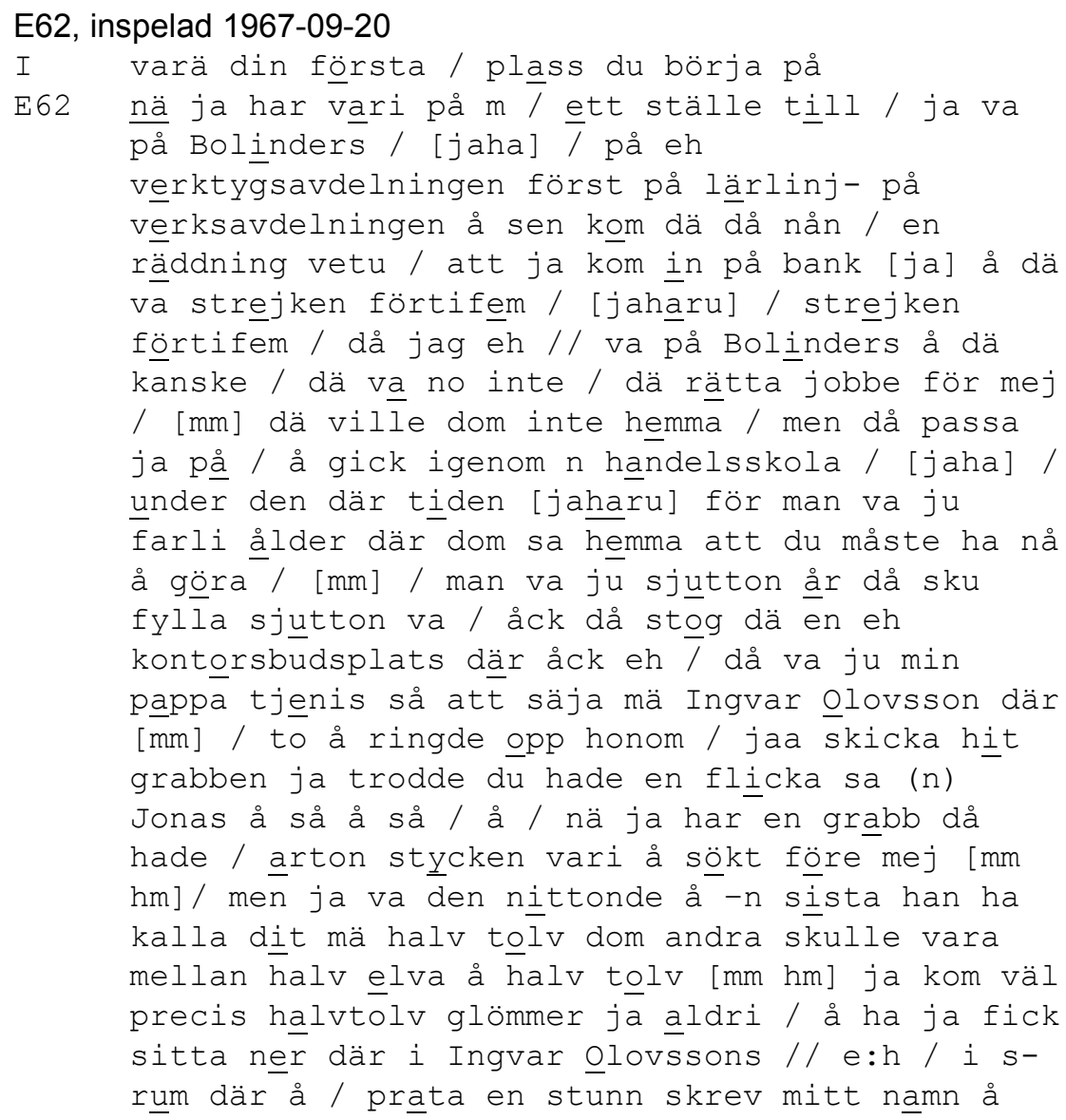


sen sa han kom vi igen / hant inte mer än hem / så ringde dä / å då sa an / a: dä ä Ingvar Olovsson / goddạ fru Bengtsson dä va längesen å så å så för / hān ä infödd Eskestunabo likväl som minnna föräldrar [mm] / börja prata lite å sa att / sonen har fått platsen å vì vill han ska börja direkt / så ja gî́ck dit å börja direkt te klockan ett / [jaha ((skratt))] jag eh / å där ä ja / än idą nu har ja vari i tjutvå år i banken [jahā] stortrivs mä dä [ja] för dä / passār no mä rätt bráa //

\section{E62, inspelad 1996-01-04}

E62 banken nittonhundraförtifem / [jaa] / då börja ja i banken ja va verktysarbetare på Bolinders men ja va mä på den stôra metallstrejken / nittonhundraförtifem

I ja dä va förtifem

E62 dä va i s- i sjū månar sex sju månar

I höll dä på så länge

E62 jaa / dä ä den längsta strejk som har vare / då / va / eh strejjkmötena i Bygget där / idrottsbyggnad som låg här nere [jah-] Bolinders måste hạ dä dä va sexton sjuttonhundra människer måste komma in / å dä va ja men / då stog dä en annons / kontorsbū / söks til̄l essebang- ti Skandiñaviska bānken som dä hette då̀ / åck eh min pappa va skol kamrat mä Ingvar olovsson här / dom va skolkamra- å Eskilstunabor / eh gamla Esktunakompisar [ja / ja] / å han ringde honom à sa kan inte du anställa min son / för han måste ha ett jobb han kan inte gåa här då hade ja börja på Handelsskolan / då gick ja å lärde mä bokföring / läste engelska / åck mátte / å körde då / på dágarna / [ja] när man gị̂ck i / man måste ju göra nånting / tyckte dōm / [ja] bir förstörda / åh då sa han så här Ingvar Olovsson ja dä va ju konstit min pappa hette Jonas / dä / va mångà år sen vi prata så här trodde du hade dótter som jạ nä ja har en grabb sa han / ((harkling)) han ä sexton år / skicka opp en men dä ä många om dä sa han / dä ä sjutut- eh $n$ 


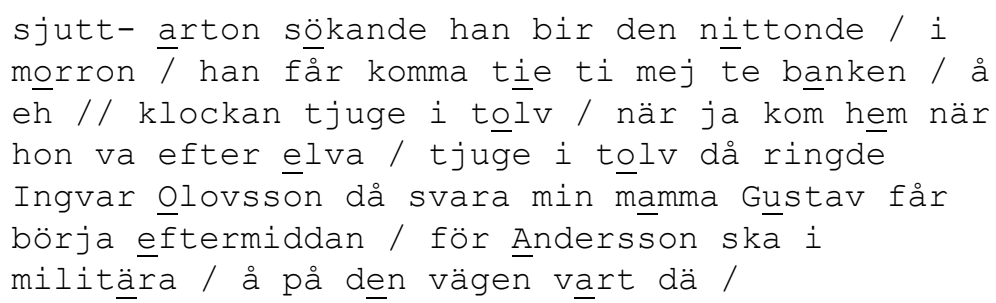

Flera uppgifter i händelseförloppet och i bakgrundsinformationen finns med och är desamma vid båda tillfällena. Vi får veta att det hände under strejken 1945, att det fanns en annons om en kontorsbudsplats, att pappan kände chefen och ringde upp honom och att chefen efter att E62 varit på en anställningsintervju genast ringde upp, pratade med mamman och sade att E62 fick börja på en gång. I dialogen finns påtagliga likheter, som skicka hit grabben ja trodde du hade en flicka ... nä ja har en grabbltrodde du hade en dotter som ja nä ja har en grabb ... skicka opp en.

Det finns uppgifter i orienteringen som har ändrats från 1967 till 1996. E62 uppger flera precisa klockslag, men han uppger olika tidpunkter i de två versionerna. 1967 blev han kallad till anställningsintervju halvtolv och 1996 tio. Precis vilken tidpunkt han kom till banken spelar ingen roll för själva händelseförloppet, men de olika tidsangivelserna är intressanta i relation till varandra, eftersom de visar hur kort tid det gick tills chefen ringde upp och därefter tills E62 började arbetet samma dag. Antalet sökande är dock detsamma i båda versionerna, även om E62 korrigerar sig själv två gånger 1996, innan han kommer ihåg siffran.

\section{Den äldsta informanten}

I de inspelningar jag gjorde med informanter i olika åldrar 1996 (paneltalarna födda 1913-1950 och trendtalarna födda 1904-1980) var mitt intryck att särskilt de äldre berättade väldigt mycket. Diskursen om äldres samtalsstil har i alltför hög grad kommit att präglas av ett bristperspektiv. I Eskilstunainspelningarna bidrar de äldre i hög grad till innehållsrika samtal, och det är fascinerande att ta del av deras berättelser och erfarenheter. I det följande återger jag en av den äldsta informantens berättelser 1996. $4 \mathrm{~K} 42^{4}$ satt i rullstol och spelades in i maj 1996 i sin lägenhet på ett äldreboende, och hon skulle fylla $92 \mathrm{i}$ juli. Hon var vital och pratade och berättade mycket. När hon inte hör säger hon oftast "förlåt", och jag upprepar eller uttrycker på lite annat sätt. Berättelsen börjar med att hon ger en bakgrund där hon berättar att hon träffade sin man när han kom och köpte en tidning när hon arbetade på pressbyråns tidningskiosk vid stationen i Eskilstuna.

4 I det nya trendsamplet 1996 ingår 72 talare, 36 män och 36 kvinnor. Varje informant fick en kod där den första siffran anger socioekonomisk grupp. Därefter står $\mathrm{M}$ för man eller $\mathrm{K}$ för kvinna. Nästa siffra anger åldersgrupp, och den sista siffran talar om informantens nummer i cellen. 
Där arbetade hon 1925-1930, innan hon gifte sig, och sålde tidningar till "både kreti och pleti":

\section{K42, inspelad 1996-05-07}

4K42 m- ja har ett särskilt minne av / de va en / en herre som kom å köpte ett / vykort / å så ett frimärke // å ko- vykortet kosta femton öre kommer j-ja kommer så väl ihåg dä . hh å frimärket kosta tie öre / men vi fick lov å lägga till ett öre på frimärket / så de blev elva öre / så de där blev tjugusex öre / så lämna han en krona / å så gav ja honom tebaka då / ja tog betalt tjugusex öre. hh så titta han på pengarna .hh å så säjer han så här / nej ja har fătt för lite sa han / väldi barsk ton / men arti som man får lov å vara bakom en disk / så sā ja neej så förklạra för honom // *jahạa då får de vara då* sa han / å så slängde han / i väg de där kuväret så de föll ända bort över .hh hela kiosken ända under skrivbordet // men äh ja gav honom / natutvis / tibạka sin krona // å: så gick han // sen andra dān när ja börja / på eftermiddan klockan tvåa / va mitt pąss då .hh säjer min kamrat i kiosken *hörrudu* sa hon // de har vart en herre här. hh en / de en liten herre han hade pipskägg å de va ju inte modernt precis på den tiden / så de va nånting [((svagt skratt))] som man gav öh märke till / .hm / å han fråga efter / han fråga efter / den andra damen som va i kiósken . hh då sa ja att du skulle komma vi den å den tiden i dag .hm *jaha* sa ja å så berätta ja för min kamrat hur han bar sej åt / .hh men du vet sa ja man får ju vara arti i alla fall // sen rätt som de va på eftermiddan så kọm han // å så säjer han så här / jaa / ja vill- / ja s- kommer sa han / å vill överlämna den här kartong- de här lilla / den här lilla / kartongen sa han .hh då va de en stôr chokladkartong / väldit vacker kartong .hh mä all möjli choklad i / å mä den ber ja om ursäkt för ja ba-b-betedde mej så tölpaktit åt / men ni va ju väldit fin emot mej för man märkte inte på er sā hon / sa han att ja vart / 


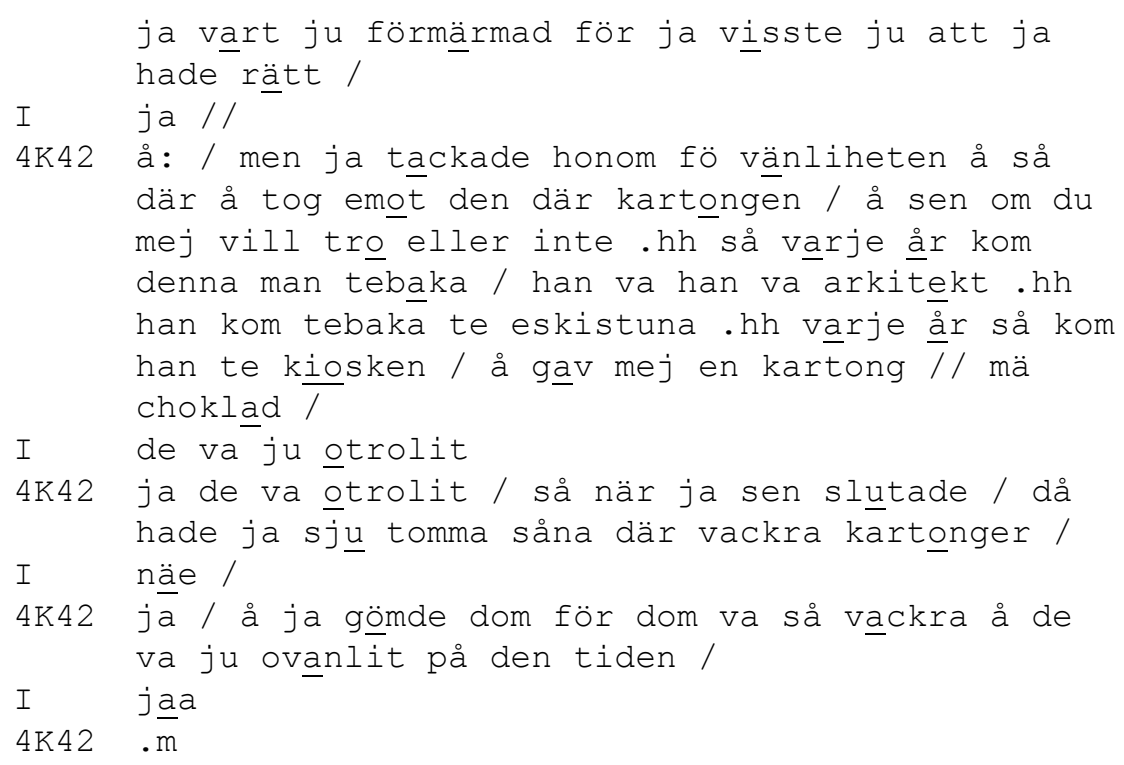

4K42 berättade med inlevelse. Man kan se att hon vet hur en berättelse ska byggas för att skapa intresse och spänning. Det går bra att applicera Labovs modell över den muntliga berättelsen på den här berättelsen, vilket jag gör $\mathrm{i}$ Sundgren $2012 .^{5}$

\section{Några berättelser från 1900-talets första decennier}

Flera informanter i mitt material ger en positiv bild av sina liv när de blickar tillbaka, trots att de kan berätta om svåra uppväxtförhållanden; många växte upp i stora familjer i små omoderna lägenheter med fabriksarbetande fäder och kan berätta hur man rökte mot löss eller slet i de tunga industrierna.

4M41 föddes 1905 och var 91 år när jag spelade in honom 1996. Han berättar om hur slitsamt det blev när fadern lämnade mamman och de sex barnen:

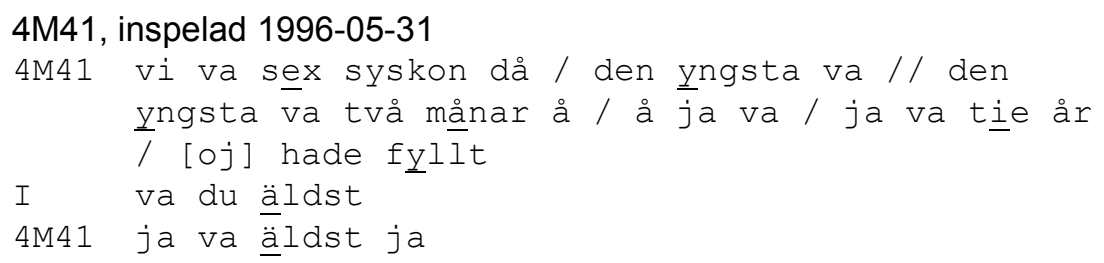

5 I Sundgren 2012 återges också fler av 4K42:s berättelser och transkriptionen i den artikeln är gjord så att överlappande tal och pauslängder finns med. 
I å han lämnade bara din mạmma mä / mä a llia barnen

4M41 ja // ja: han orka inte mä / [nä:] / de va väl andra intressen som / som gjorde de också att han // ville komma / (å va) / va egentlia orsakerna va de ä kan de ä svårt å säja ja / [ja] / de va

I men de måste ju ha blivit väldit jobbit för er / [ja] / din mamma

4M41 de blev de ju / de blev ju / de blev jobbit för henne å de blev jobbit för oss barn mä / de va jü inte den / den eh så kallade socialvården då som de ä nu inte [nää] / de / de va jämnt ingenting dä / helst ville väl kommun / ta hann om oss barn de kommer ja ihåg att de va / prāt om de / att kommun skulle / ta hann om oss å // å: / å: / de va va ju d- så på den tiden att / de va ju mest / s-bönder å så vidaré som / (för) barna skickades / omkring till då / som to ha- // å va man då så man till exempel va // någotsånär så man kunde börja på å arbeta hjälpa tíll så drog dom ju nytta av de å // de va ju // men mamma ville inte släppa oss / helt enkelt (utan) hon ville / ta hann om / hon fick ju lite / lite / hjälp de / kommer ja ihåg / tror de va /// efter mycke om å men å å / å å så där å å // spekulêrande på alla möjliga vís så fíck hon / tie kroner i veckan / [ojj] / att jaa / å de / tie kroner va ju mycke pengar då på sätt å vís men de va ju ingenting att / att försörja / en familj å å de va under / under första världskrige då också som / [ja] de va ganska svărt för // inte bara de va mỵcke svårt för // folk i våran / socialgrupp kan man säja // som inte hade pengar / att / att köpa / för / för de va // då va de / mycke / såna här // svarta / svarta börshandel / mä matvarer / [ja] à allting //

I å så många barrn som hon hade

4M42 ja / jo de vā / de v- / de: / de de va / de va väldit / slitsamt å hårt

I kommer du bra ihåg de här

4M42 ja ja kommer väldit bra ihåg hurdant / hurdant de va för att ja / ja fick ju själv lov å hjälpa till så väldit t-ja va ju bara tie år 
då / å ja va väl inte så stor å stark heller // fast eh / stỵrkan / kanske // sitter på ett annat vís / [ja:] / hos både mēj å mâmma / mamma vā ju också litten å / inte så stârk men /

I men klarade ändå av de här

4M42 de / de gjôrde hon

2M42 berättar om att hans mamma dog när han var 10 år och att fadern lämnade de fem barnen ensamma efter några år. I följande utdrag berättar han om bostadsförhållandena i sin barndom. Han var född 1910, dvs. 86 år vid inspelningstillfället 1996:

\section{M42, inspelad 1996-05-21}

2M42 men rummena va ju små / ja vet att ja va där å titta på dom där rummena / lāngt efteråt / just när dom skulle börja riva de där / [mm] / å man kunde inte fatta att man kunde bo i ett sånt där // de va ju inte på långt när så stort som de här köket

I va de inte [nej] / oj va de kallt då

2M42 jā visst va de kallt / de va ju bara en

kakelugn / å trägolv vet du // [ja] där sprang

rătterna fram [ğjorde dom] ja dom grävde hål på på / på på / gollvena vet du å kunde gna- kn̄aga opp där / så då fick man stoppa i glasbitar à så där för dom ${ }^{\wedge} \mathrm{s}-\mathrm{skull}^{\wedge}$

I va inte de otäckt mä råttorna

2M42 jo va otäck- / men de de de ví va inte ensamma de va ju överallt

I ja de förstår ja ju / de vet ja

2 M42 ja / å dessutom / de som jạ tyckte va värst de va (ju) vägglöss /

I va de värre

2M42 de har inte du vari mä om

I nej inte vägglöss

2M42 nä / nä / men du har hört talas om de

I jo/ ja men berätta

2M42 ja / ja de va ju vägglöss som dom / kröp ju här e- / efter väggarna / natutvis // åck // då då när när dom kröp i take då kröp dom opp i take så här sen släppte dom sej nẹ till / till där där vi låg å sov / å så / så bet dom // på bena på på oss ungar så där man fick ett nypp där å $\operatorname{tog} / /$ 
I då fick man loppbett

2M42 ja då då de va inte lopp de va lus / vägglöss

I vägglöss ja heter de

2M42 jā vägglöss / å lukta illa av et

I lukta de också

2M42 ja de lukta

I va de allitså så mycke löss så man direkt såg dom vandra efter väggarna

2M42 ja ja de de lukta av dom när dom kom nêr för att man / kröp ner / dom kröp ner då

E72 föddes 1913 och spelades in andra gången när han var 83 år. Här berättar han om hur hans mamma och han plockade bark för att ha till att elda och om hur hans pappa skaffade mat under första världskriget:

\section{E72, inspelad 1996-01-16}

I då hade ni inte så så / fett precis

E72 nä: nä: / de låg en stor végård / där / Obs /

vet du var dom hade [ja oh ja] E V Nilssōn hade en stor vegård där brägård vegård / å ja kommer ihåg / mamma å ja gick dit å / plocka bark // de va ju så jädra stora vestaplar dom lasta av där [ja] / å / bark föll ju dän mycke / utav träna // å då fick vi lov å plocka opp barken / om vi / ville / så mammā hon hade skottkärra gick å å sköt^ [oj] vi bodde ve / ve

Skarpskytten då de ligger på den här sidan

järnvägen / fick vi dra ner till kȳrkbron å / opp gatan där ((hostar)) / jodå

I skulle ni elda me de eller

E72 ja mamma skulle ha ti tvätten ti tvättved / [ja] eller ja te elda mä // så ((skratt)) när man tänker efter / hur mamma / dom där långa kjolarna å de där / [ja] / å hụckle på huvve // ja / jodå så / nog fick dom väl göra skäl för sej allt

I de va andra tider ändå de [jaa] (var) maten då hade nì bra mä mat

E72 jo vars ma- pappā va dukti å skaffa mä mat // över krigsårena då när de va // svårt å // han / satt han å cỵkla neråt Västermo å / Julita [mm] / på lörda å sönda

I Julita [ja] de ä långt 


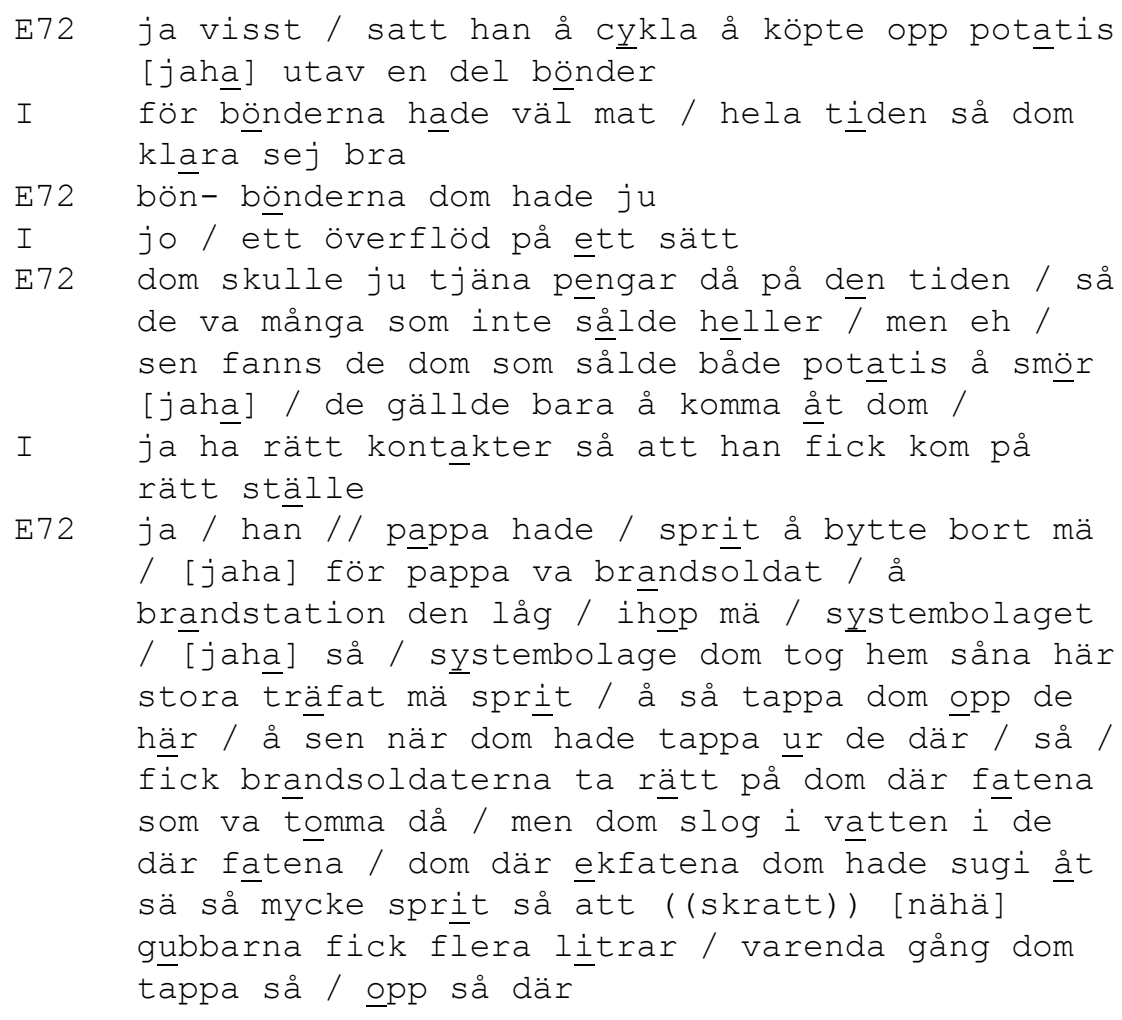

3M43 var den fjärde generationen som arbetade på Bolinder Munktell. Farfadern och fadern arbetade som metallgjutare och efter att ha arbetat som eldare och maskinassistent på olika båtar fick 3M43 arbete som reparatör på Bolinder Munktell. Han gick till sjöss när han skulle fylla 16 år och han berättar hur det gick till när han fick det första jobbet. Pappan skrev på intyget, eftersom han själv arbetade i gjuteri och inte ville att sonen skulle få ett så slitsamt arbete. Åren till sjöss satte emellertid sina spår, och före det här utdraget sade han att trodde att de gjort att han nu var så darrig. 3M43 föddes 1915 och var alltså 81 år när jag spelade in honom:

\section{M43, inspelad 1996-05-28}

I men du tror på allvar kanske / att de kan ha å göra mä //att du va till sjöss

3M43 ja ja trôr de // ja förstörde sỵn då också dä / brände opp ögonen nästan [hurdå] / ja / stirra in när man e- ja va eldare börja som då / kunde man inte ha glasögon på sä dä vart för varmt (detta) 
I o jj så hemskt hu- hur gammal var du när du gíck till sjöss

3M43 ja ja va väl // ja hade inte fỵllt sexton år när ja / för ja fick lov å ha påskrivet utāv / min far / intyget / de gick fort de där / ja fick reda på // nere ve eh / eh stan att dom hade gôtt om jobb ve oxelösund / där ve hamn å // å ja hade en racercykel ja höll på å åkte lite å kladda / åh / ja åkte ner dit en morron å / träffáa den där chefen ve hämn där // han tja du ä no lite för ung sa han du skulle ha ett par år till på dej sa han då stô de en gụbbe brevi å hörde där / sa han / vilil du ha jôbb sa han / ja: sa ja / ja du kan få jobb hos mej på den här båten sa han ja ska ha en lämpare sa han / ja spetsa örona ja vart ju intresserad // å så sa han / ä rä så du vill hạ de så ska vi mönstrá folk i morron / i / Nyköping / å de va ett klockslag på förmiddan om de va elva eller nå // ja sa ja men du måste ha / intyg utav dina föräldrar å åldersbetyg å gréjer sa han / å de gick ju bra på den tiden för då va pastorsexpedition öppen på kvällarna / så ja cȳkla hem mä en jäkla fart å // morsan hon grät ( (skratt))

I ja de förstår ja

3 M43 ja / å då då han sa du får göra va fân du vill bara du inte börjar i gjuteri sa han så I va de då han sa de

3 M43 ja han skrev på de där / [ôj] de fanns ju inga jobb / [nä:] de va ju ingenting / de fanns inte ett dugg / å välja på

I va de nitton- i början av trettitalet ja

3M43 ja tjunie tretti va de [ja: $/$ oj oj oj] ja hade I vadå cỵklade hem de va väl långt

3M43 ja de ä väl en // nie tie mill [( (skratt))] å ja cykla tebaks dan efter ocksàa /

I $\quad \underline{\underline{y} k l a d e}$

3 M43 jaha $^{\wedge}$ visst [( (skratt))] å ja va där nere klockan élva å mönstra / [oj] men då kom ja underfund mä va de va men de va efteråt de va en så jäla dåli båt de där / 


\section{Tre kvinnor födda på 1930-talet}

E67 föddes 1928 och var alltså 68 år när jag spelade in henne 1996. Hon var nummer tre $\mathrm{i}$ en syskonskara på sju, och de första tio åren av hennes liv bodde hela familjen i ett rum och kök. Därefter flyttade de till en modern lägenhet med två rum och kök i ett barnrikehus. Mamman fick åtta barn på tolv år, men en flicka dog vid sju månaders ålder. E67 berättade om att hon började arbeta efter sjunde klass, medan de två yngre bröderna kunde studera och få bra jobb:

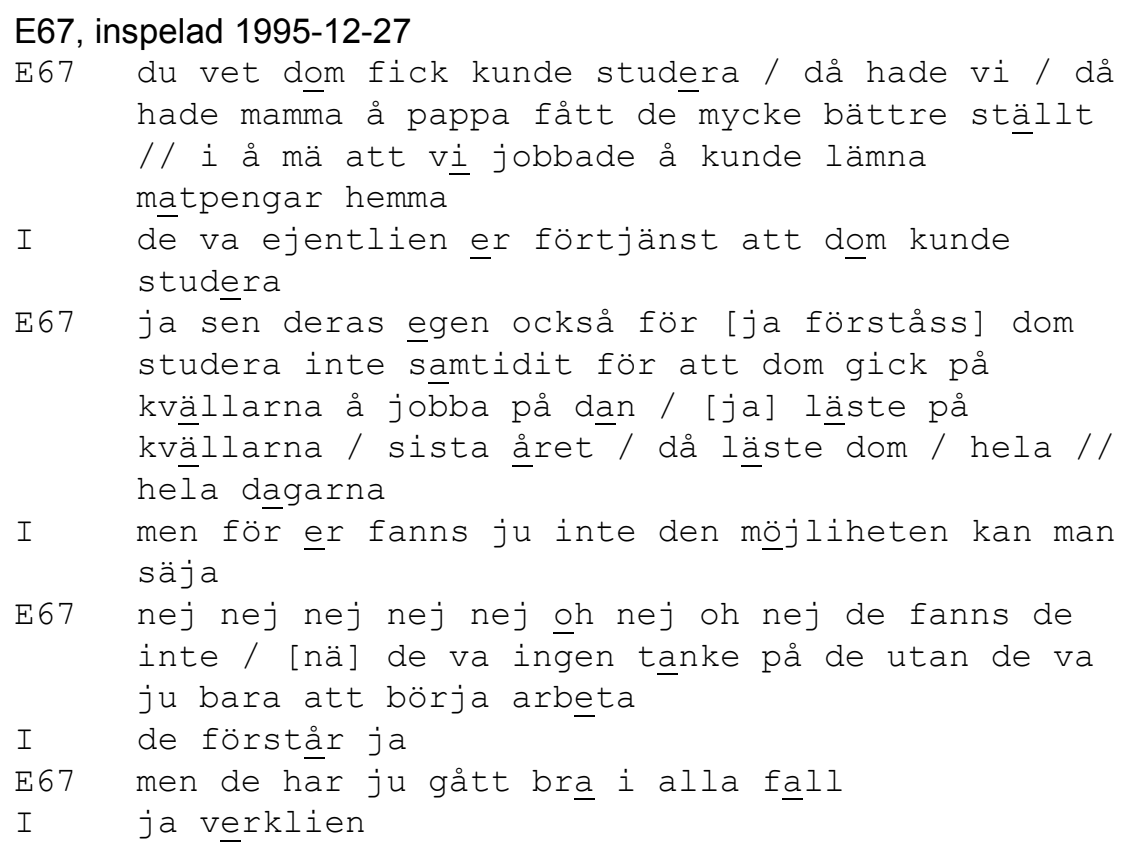


I sydde hon klänningar till er flíckor då

E67 jaa

I va de både flíckor å poojkar

E67 mm // de va de

I sydde hon fina klänningar

E67 ja // ja kommer ihăg vi har nå gammalt ko:rt / fast ja vet inte var ja har de nül men då hade víflicker vi va ju / ja äldst / min äldsta bror hade / inte de // han som ä äldst utav oss allihopa / mén víflicker hade i álla fall såna här sjömansklänningar / randit kadettyg blått å rött å vitt smalrandit [jā] / mä săna här /

I va fint

E67 å pojjkarna då dom y- yngsta pojkarna dom hade / kortbyxer å // å skjôrter i samma så vi va lika $\mathrm{kl}$ ädd

I $\quad \underline{j}$ va fint

E67 de kommer ja ihåg väldit tydlit

I mitt slumpmässiga urval till trendstudien visade det sig att en av informanterna, 4K41, var yngre syster till E67. Båda berättade om att E67 när hon fick sin första lön köpte en docka till sin lillasyster. I det följande berättar 4K41 om hur trångt det var i bostaden med ett rum och kök. När jag spelade in 4K41 1996 bodde hon och hennes man i sju rum och kök. Hon var född 1933 och var alltså 63 år när jag spelade in henne:

4K41, inspelad 1996-04-09

4K41 så vi måste ju ha vart eh / sjü // sjụ barn / i ett rum

I men hur fick ni plats

4K41 ja de vet ja inte / ja prata mä en gammal

farbror en gång / som hade / de fanns enkelrum o-ppepå / [mm] / å / skog hette han / kommer inte ihå va han hette i förnamn / prata mä $\mathrm{n}$ ofta nere på / ve Åhlens där när eh då på den tiden ja jobba för hā̄ gick å åt frukost på Åhlens [ja] å han tala om att / Johan / som ä född // eh trettifém // han låg påa diskbänken / /

I låg han $\mathrm{p}-$

4K41 men de ko- de har inte jạ nå / jaa de de sạ han att han låg på diskbänken /

I kom den där farbrororn ihåg de 
4K41 att dom hade bädd- ja att dom hade bädda på diskbänken men de de ä ju nånting som inte ją / de kan ja ju inte / säja att de ä sant heller ${ }^{\wedge}$ för de vet ja inte ${ }^{\wedge}$

I ((skratt)) han ramla inte ner i alla fall

4K41 nä vi hade väl nån sån där útdragssoffa där låg man väl flera stỵcken antar ja

Det fanns inget vatten inne i lägenheten, utan en pump på gården. 4K41 var 5 år när de flyttade till barnrikehuset. Det fanns många barnrikehus i Eskilstuna och de ansågs ha hög standard. De byggdes med två rum och kök. Det hus som E67 och 4K41 flyttade till byggdes 1935-36 och alla lägenheter hade två rum och kök. Där bodde åtta familjer med sammanlagt 60 barn.

Liksom sin syster berättade 4K41 om att mamman såg till att barnen var fint klädda. Bland annat vände hon på gamla kläder och sydde om till nya fina plagg.

2K43 var också född 1933. Här berättar hon om hur hon 1948, när hon hade börjat arbeta, blev skickad till EPA för att köpa nylonstrumpor till chefen:

2K43, inspelad 1996-08-29

2K43 där va Centralföreningens kontôr när ja börja jobba nittonhundraförtiåtta / [jaha ój] tänk / ja där börja ja jobba då / å då då fanns de inte nylonstrumper de tycker jā ä så rolit de brukar jā berätta / då fanns de inte nylonstrumper / utan / dom hade ju börja på å kommi då / [ja] / å / men Epa / dom hade fick jü in nylonstrumper iblann / de va ju strumper strumpbyxer fanns ju inte då / [nääj] nä / utan / då va de ju strump- / du då fick ja ledit å gå å stå i kö på Epa å köpa nylonstrumpēr / [nähä] för chefen / mm [nähä] joo [((skratt))] å då fick man väl inte köpa så många så ja köpte väl så många ja fick då för att då va vi ju flêr då / tjejer ellêr så där då så att ja vi va väl en sjü / ja fem sex stỵcken i alla fall så / .mm / de ä de ä en sån där grej som ja kommer ihåg när ja stog där / då va de ju såna här / dîskar också vet du de va ju i-inte självbetjäning då utan de va ju / expeditter ( ) ja /

I men va festlit köpte du strumpor åt alla då 
2K43 ja då köpte ja då fick ja gå / då fick ja ledit för att ja skulle få gå å köpa strumper

I men hu- hur visste du de va väl olikka storlekar [ja ((skratt) ) ] å fy så svårt

2K43 de hade ja väl uppskrivet eller om de bara va en storlek ja vet inte ${ }^{\wedge}$ [å f $\underline{y}$ så svårt] å så va de ju söm på dom också vet du

I ja de va sö- va dom dyra tror du

2K43 de kommer ja inte däremot inte ihåg

I men de va väl som man knäppte mä såna här [jaa] på [ja] höfthållare eller [jaa] /

2K43 men du vet de va ju så / åh / å gúd alltså / första nylonstrumperna ja / hade / de dom dom / fick vi tag i när ja konfirmeras de kommer ja ihågg [nähä]/ de vạ ju när gjorde ja de ja de va ju nåra ja de va ju ungefär samt-

I före de där ungéfär [.ja mm] eller va de då 2K43 ja de vạ de ju förstås / ja kanske åre före då I men föré de då hade man såna här

2K43 jaa hade mān ju ja såna här andra / silkestrumper hette re ju [jā] du vet såna lite tjocka de finns ju dom tanter som har fortfarande / lite /

\section{En av de yngsta paneltalarna inspelad en tredje gång}

De två yngsta paneltalarna föddes 1950, samma år som jag. När jag spelade in E101 första gången 1996 hade han varit socialt mobil sedan 1967 och blivit bankdirektör. Jag spelade in honom en tredje gång 2018, det år då vi båda skulle fylla 68. Här berättar han om hur han 1971 gick in på en bank och frågade om det fanns något jobb:

\section{E101 inspelad 2018-02}

E101 sen eh // när ja mucka från lumpen // tog tåge hem från Linköping å / hade mücka / å / då hade ju fârsan förstås vari påa en också att nu / ser du tíll å skaffar dej ett jobb de första du gör / när du när du kommer hem nu de ä à gå till arbetsförmedlingen // elīer nån annan / de första du gör / som / du måste hā ett jobb nu / de va inte så lätt mä jobb heller då

I va de inte de

E101 nej inte va ja kommer ihåg / inte så där / eh ja hade vâri på CE Johansson då emellañ å jobba där lite grann / mä éfterkalkyler à va dä va / 
å de va inte så rolit // men sen eh / tänkte ja / jāklev av / på station / kom från Linköping å / de fanns som hette Göteborgs bank där nere mitt emot högskolan [jaha] på Drottninggatan där nere / å̀ där är / nu är de nån res- nu har väl hotellle de å sen ä de nån godisbutik där I ja just de där [ja] de ä snett mitt emot där ja jobbar ju

E101 å där hade Göteborgs bank ett kontor / [mm å ja hade ju läst eh // jo sen hade ja ju läst också sen läste ja ju in gymnasiekompetens i dom viktigaste ämnena företagsekonomi å sånt I de va ju bra gjort

E101 ja / å men ja koncentrera mej på vissa ämnen så ja hade ju gymnasiebetyg i / i dom här ämnena som behövdes så att säja / så ja tänkte ja går in ja gick ner för Drottninggatan // tänkte ja går in å frăgar om de finns nå jobb här [mm] / på Göteborgs bank då [( (skratt)) ] ( (skratt)) å ja vet bankdirektörn / ja kom ju in där långhåri ((skratt)) å han sa / jahạa ja no behöver vi folk allt han va ganska dominant å [ja] auktoritär å / va / högröstad å sen titta han på mej å så sa han / upp å ner så där / glasögona/ å du ska / du vill bli bankman sa han / ja ja hade tänkt de / åh fy fān bevare mej väl ((skratt))

I sa han de

E101 jā vi får se / ja ringer i morrn / får vi se hur de går / dan därpå då rîngde han / när kan du börja [nää] / joo / å han väldit högröstad va / ja ja kan börja i morrn sa ja / ja håre får du väl ha kvâr för dé ligger ju i tídēn / skrek h- han skrêk allså

I $\quad$ sa han så

E101 håre kan du ha kvar men / men se till å sätt på dēj nån tåt runt halsen / när du kommer för då skulle man ju ha kostỵ å sjlips å grejer / å sen dạn därpå då hade ja börja där /

I men va festlit

E101 ja å de va de va ju inga inga större merkuri urval på den tiden

I men du gick ju bara in där

E101 ja gick in där å / å två dar tre dar efter hade ja va ja nere à hade börja jobbo 
I han tyckte väl du va framåt ändå rå

E101 ja ja vet inte dom behövde väl folk / [jaa men]

/ för dom va alltså dom expanderā å dom va i ett skriande behov av folk_å de va

I han acceptera till å mä att du hade långt hår

E101 ja jā de där ligger ju i tiden ja tänkte de /

ja sa åt farsan kanske (ja skulle) gå å klippa mej då innā / ja de gör du som du víll sa han / ja tänkte ja chansar

I men vicket år va de här tror du

E101 eh nitton hundra / eh / sjutti ett

I ja ja tänkte de / [ja] de ä klärt du va ju / Beatles / började ju me långt hăr då [ja] de va ju fint tyckte ja

E101 jaa $/$ å de va de dom hade ju börja redan innan

I à när man tittar på korten av dom dom hade inte så långt hår [nää] från början

E101 nä men de hâde dom inte påa den tiden [nä] va de ju revolutionerande

I de va de ju vêrklien

E101 jaa / så att / men eh / men sen nä håre de gör ingenting men se bara till att du ä någorlunda hyfsat klädd / å sen på den vägen blev de / de va förti àr i bank

\section{Positiva röster om staden Eskilstuna}

Flera informanter uttrycker att de tycker om Eskilstuna och trivs i staden., och jag ger i det följande några exempel på det. Först talar $1 \mathrm{M} 41$, född 1923, bland annat om den breda, fina ån i Eskilstuna:

\section{M41, inspelad 19960320}

1 M41 man bygggde ju / rätt hemska / hụs på sina / ställen / [ja] Eskilstuna stad kanske kanske mer $i$ andra städer än i Eskilstuna

I ja tycker du att eh / de ä ganska fint ändå i Eskilstuna stad

1 M41 ja ja tỵcker de / ja ja tỵcker faktist de I du tycker om stan

1 M41 ja / ja tycker om stan [( (skratt))] / jo men / om du har ån vi vi har ju en [ja den ä fin] stor öppen [mm] å / den ä ju bred à fin / eh / den ä ju // verklien / ja du tala om Västerås förut den ä ju / va heter den nu å- ä de [Svartån] Svartån ja den ä // den märker man 
inte mycke av [nä den ä bara 1-] men men här med med / fâllen ifrån Tunafors å även om man går ännu högre opp [mm] Snopptorp där uppe [mm] å bort mot / skjulsta å Vîlista

I ja de ä jättefint

1M41 å sen går vägen ner här / stâdsparken ä ju en väldit fin oas med de gröna på ena sidan å sen / den den rätt fina vattenspegeln där / å så kommer du över mot strö̈msholmen / som ja skulle önska att man kunde göra nånting mera av / [ja] att ha nånting på / nån verksamhet på på nåt vis

I för där är de ju inte mycke

1M41 för där är de väldit lite / människor men de de ä en väldit fin plats / när ja va när ja va när ja va barn så-/ fanns de ju en / servering där / [jaså] trä- träslott ^kan man nog källa de för ${ }^{\wedge}$ [jaha $]$ / eh som / mä servering men de de revs sen

I va va de / en restaurang

1M41 de va en restaurang / ja

I va hette den / kommer du ihåg de

1M41 nja / Strömsholmen / hette den

I ja strömsholmen kanske den hette

1M41 den hêtte no strömsholmens restaurang

I du prâtar så vackert om Eskilstuna så ja börjar tycka att de ä riktit

1 M41 ((skratt)) att de ä fint här / ja många talar ju lite negativt om Eskilstuna / meñ / eh / tycker de ä fel / [mm] / att de ä en / den ligger fint tīll här / den ligger vackert till å sen / om man tänker på Mälaren / de ä ju I ja naturen finns ju inpå 1M41 naturen finns på / å Hjälmaren å sen har du [ja] / annan natur som ôckså ä / historisk åck vacker på sitt sätt

I jā i Sörmland runt omkring ä ju fint också 1 M41 de ä mycke fint

Slutligen återges ytterligare ett par positiva omdömen. E67 har presenterats tidigare i den här artikeln. E27 föddes 1919 och 2M41 1930. När jag spelade in E27 bodde hon högst upp, på sjätte våningen, i en lägenhet med bra utsikt över omgivningen. 
E67

E67 ja tycker Eskilstuna ä bra // ja har aldri haft nå problem mä att eh / bọ här eller / ens drömt om att / flỵtta nån annānstans / [nääj] // jā har trivas i alla fall hela tiden //

E27, inspelad 1996-01-29

E27 mycke grönt Konstmuseet rakt över ån å [jaa] / ja å // à närāa läroverket ser ja / härifrån / ja

I fin utsikt

E27 ja de ä dä verklien

I men de ä ju också Fors kỵrka

E27 ja de ä de den ä så vacker nu när den är upptänd så ja ser / Klosters kyrka också på kvällen när den ä upptänd / ·ja [fantast-] den ä fin ja har verklien b- blivit belönad mä utsikt / .ja

I de ä väldit rolit å komma upp här å se / tycker ja

E27 jáa / va som / va som va väldit fint här i jul då när vi hade a- till advent å så ja tänker på / på läroverket / [jaa] att eh då har dom allra högst så har dom ju de ä ju som ett torn / [mm] högst upp

I de vet ja

E27 å där hade dom / satt / en adventsstake // å den lyste så fint där uppe högst upp / hela tiden

2M41, inspelad 1996-04-22

2M41 om man tar vara på tillfällena / [mm å / har ögona öppna så / ä dä en jäkla / fin stad

\section{Några avslutande reflektioner}

Efter mina inspelningar med Eskilstunabor 1996 fick jag en helt annan känsla för staden än jag tidigare hade. Jag är inte född i Eskilstuna utan kom hit 1978 för att arbeta på ett gymnasium. Eskilstunainformanterna bidrog både med sitt språk och sina livserfarenheter, och efter att ha intervjuat så många Eskilstunabor och tagit del av deras berättelser kändes Eskilstuna också som min hemstad.

När jag hade valt berättelser till den här artikeln visade det sig att de flesta utspelar sig under 1900-talets första hälft. Eskilstuna hade förändrat sig mycket från den tiden till 1996, då jag gjorde inspelningarna. Många 
hade växt upp under fattiga och slitsamma förhållanden och hade varit med om stora förändringar.

Jag hoppas att jag också har lyckats förmedla hur givande det kan vara att samtala med äldre och lyssna på deras berättelser, eller i dag borde jag kanske inkludera mig själv och skriva våra i stället för deras berättelser.

\section{Litteratur}

Bruner, Jerome (1987), 'Life as narrative", Social Research 54: 11-32.

Eriksson, Mats (1997), Ungdomars berättande. En studie $i$ struktur och interaktion. (Skrifter utgivna av Institutionen för nordiska språk vid Uppsala universitet 43.) Uppsala.

Goffman, Erving, (1959), The Presentation of Self in Everyday Life. New York: Anchor Books.

Labov, William (1972a), Sociolinguistic Patterns. Philadelphia: University of Pennsylvania Press.

Labov, William (1972b), "The transformation of experience", i W. Labov, Language in the Inner city. Philadelphia: University of Pennsylvania Press, s. 354-396.

Labov, William \& Waletsky, Joshua (1967) "Narrative Analysis: Oral Versions of Personal Experience", i June Helm (red.), Essays on the Verbal and Visual Arts: Proceedings of the 1966 Annual Spring Meeting of the American Ethnological Society. Seattle: University of Washington Press, s. 12-44. Omtryckt i Christina Bratt Paulston \& G. Rickard Tucker (red.), 2003: Sociolinguistics. The Essential Readings. Malden, MA: Blackwell, s. 74-104.

Linde, Charlotte (1993), Life Stories. The Creation of Coherence. New York: Oxford University Press.

Nordberg, Bengt (1982), "Sociolingvistisk datainsamling", i M. Thelander (red.), Talspråksforskning i Norden. Mål - material - metoder. Lund: Studentlitteratur, s. 92-119.

Norrby, Catrin (1998) Vardagligt berättande. Form, funktion och förekomst. (Nordistica Gothoburgensia 21.) Göteborg: Acta Universitatis Gothoburgensis.

Norrick, Neal R. (2000), Conversational Narrative. Storytelling in Everyday Talk. Amsterdam \& Philadelphia: John Benjamins.

Polanyi, Livia (1989), Telling the American Story. A Structural and Cultural Analysis of Conversational Storytelling. Cambridge, Mass.: MIT Press.

Schegloff, Emanuel A. (1997), "Narrative Analysis' Thirty Years Later", The Journal of Narrative and Life History 7:1-4: 97-106. Omtryckt i Christina Bratt Paulston \&

G. Richard Tucker (red.), 2003: Sociolinguistics. The Essential Readings. Malden, MA: Blackwell, s. 105-113.

Schiffrin, Deborah (1996), "Narrative as self-portrait. Sociolinguistic constructions of identity", Language in Society 25, s. 167-203. 
Schilling-Estes, Natalie (2002), "Investigating stylistic variation", i J.K. Chambers, Peter Trudgill \& N. Schilling-Estes (red.), The Handbook of Language Variation and Change. Malden/Oxford: Blackwell, s. 375401.

Schilling-Estes, Natalie (2008), "Stylistic variation and the sociolinguistic interview: A reconsideration", i R. Monroy \& A. Sánchez (red.), 25 years of Applied Linguistics in Spain: Milestones and Challenges. Proceedings of the $25^{\text {th }}$ AESLA Applied Linguistics Conference. Murcia: Universidad de Murcia, Servicio de Publicaciones, s. 971-986.

Sundgren, Eva (2002), Aterbesök i Eskilstuna. En undersökning av morfologisk variation och förändring $i$ nutida talspråk. (Skrifter utgivna av Institutionen för nordiska språk vid Uppsala universitet 56.) Uppsala.

Sundgren, Eva (2003), "Händelser i livet blir till berättelser. Hur samma händelser skildras med 30 års mellanrum”, i Bengt Nordberg, Leelo Keevallik Eriksson, Kerstin Thelander, \& Mats Thelander, Grammatik och samtal. Studier till minne av Mats Eriksson. (Skrifter utgivna av Institutionen för nordiska språk vid Uppsala universitet 63.) Uppsala, s. 249-258.

Sundgren, Eva (2012), "'dä blir minnen av allting' - Äldres samtalsstil med fokus på berättelser", i, Sture Packalén (red.), Litteratur och språk, Nr: 7 (2011). Akademin för utbildning, kultur och kommunikation, Mälardalens högskola, s. 127-141.

Sundgren, Eva (red.) (2013), Sociolingvistik. 2 uppl. Stockholm: Liber.

Wolfson, Nessa (1976), "Speech events and natural speech: some implications for sociolinguistic methodology", Language in Society 5, s. 189-209.

Öberg, Peter (1997), Livet som berättelse. Om biografi och åldrande. (Comprehensive summaries of Uppsala dissertations from the Faculty of social sciences 62.) 